\title{
THE MYSTERIES THAT SURROUND KAWASAKI DISEASE: A LITERATURE REVIEW
}

\section{ORIGINAL ARTICLE}

ROSSI, Karoline ${ }^{1}$, MOREIRA, Danilo José Silva², FONSECA, Juliana Brito da ${ }^{3}$, VASCONCELOS, Suzana dos Santos ${ }^{4}$, OLIVEIRA, Vinicius Faustino Lima de ${ }^{5}$, DIAS, Claudio Alberto Gellis de Mattos $^{6}$, OLIVEIRA, Euzébio de ${ }^{7}$, DENDASCK, Carla Viana $^{8}$, ARAÚJJ, Maria Helena Mendonça de ${ }^{9}$ FECURY, Amanda Alves ${ }^{10}$

ROSSI, Karoline. Et al. The mysteries that surround Kawasaki disease: a literature review. Revista Científica Multidisciplinar Núcleo do Conhecimento. Year 06, Ed. 04, Vol. 05, pp. 52-64. April. ISSN: 2448-0959, Access link: https://www.nucleodoconhecimento.com.br/health/kawasaki-disease, $\quad$ DOI: 10.32749/nucleodoconhecimento.com.br/health/kawasaki-disease

\section{SUMMARY}

Kawasaki disease (KD) or Mucocutaneous Lymph node Syndrome is a systemic vasculitis, which mainly affects children under five years of age with Asian descent, but can also reach other age groups, as well as any other breed. The clinical picture of KD has three stages: acute febrile stage, in which conjunctival congestion, oral mucositis, erythema, flaking, polymorphic rash and laterocervical lymphadenopathy,

\footnotetext{
${ }^{1}$ Medical academic. Federal University of Amapá (UNIFAP).

${ }^{2}$ Medical scholar. Federal University of Amapá (UNIFAP).

${ }^{3}$ Medical academic. Federal University of Amapá (UNIFAP).

${ }^{4}$ Medical academic. Federal University of Amapá (UNIFAP).

${ }^{5}$ Medical scholar. Federal University of Amapá (UNIFAP).

${ }^{6}$ Biologist, PhD in Theory and Behavior Research, Professor and researcher of the Degree Course in Chemistry of the Institute of Basic, Technical and Technological Education of Amapá (IFAP).

${ }^{7}$ Biologist, PhD in Tropical Diseases, Professor and researcher of the Physical Education Course, Federal University of Pará (UFPA).

${ }^{8}$ Theologian, PhD in Psychoanalysis, researcher at the Center for Research and Advanced Studies (CEPA).

${ }^{9}$ Doctor, Master in Teaching and Health Sciences, Professor and researcher of the Medical Course of Macapá Campus, Federal University of Amapá (UNIFAP).

${ }^{10}$ Biomedical, PhD in Tropical Diseases, Professor and researcher of the Medical Course of Macapá Campus, Federal University of Amapá (UNIFAP).
} 
appear as main symptoms; the subacute stage, which occurs at the end of fever, and leads to the appearance of skin flaking in the limbs, arthritis, arthralgia and thrombocytosis and finally the stage of convalescence that arises when symptoms are almost dissipating and continues until their normalization. The most used treatment occurs from the administration of intravenous immunoglobulin, which for better prognosis of the pathology should be initiated early.

Keywords: Mucocutaneous Lymph node Syndrome, Vasculitis, Arteritis, Fever, Kawasaki.

\section{INTRODUCTION}

Kawasaki disease (KD) is a systemic vasculitis that affects small and medium-caliber vessels and mainly affects children under 5 years of age, being one of the reasons for heart disease during childhood (HUANG et al., 2015; MAGALHÃES, 2008). The etiology of KD, that is, the causation agents of this disease, are not known. However, some clinical and epidemiological aspects propose possible infectious reasons (FERRONATO et al., 2010).

$\mathrm{KD}$ is the second most common vasculitis in pediatric age, affecting mainly children less than half a decade old (90\%). It is uncommon in children under 6 months and older than 8 years, who, however, are more prone to the development of coronary aneurysms. On a global scale, there is a variation in occurrence, with Japan being the most affected country, with an annual incidence of 110 to 150 cases per 100,000 children under 5 years. Considering the calculation of incidence rates in every 100,000 children under 5 years of age, in the United States of America (USA) KD is the most common cause of childhood-acquired heart disease, ranging from 9.1 to 32.5 cases, occurring more frequently in those of Asian and Pacific island descendants (32.5), intermediate in African-Americans (16.9) and Hispanics (11.1) and uncommon in Caucasians (9.1) (ALMEIDA et al., 2010; CASTRO; URBANO; COSTA, 2009; RODRIGUES et al, 2017). 
KD has a higher prevalence in the Asian population, with emphasis on Japanese, affecting mainly children. There is a report of an annual incidence in Japan and Korea of up to 100 cases per 100,000 inhabitants, while in the Caucasian race the occurrence is between 6 to 10 cases per 100,000 inhabitants under the age of half a decade. In Latin America, it is estimated that there are 3 cases per 100,000 inhabitants, thus evidencing a lower frequency of this pathology in non-Asian populations that are not descended from Asians (SCARDINA et al., 2007). Regarding the mortality rate associated with $\mathrm{KD}$, it is very low, as it is less than $0.1 \%$ (BARCA et al., 2019).

The incidence of KD varies geographically in the world, being more prevalent in Japanese descendants, suggesting a genetic predisposition of the disease, in addition to possible causatous agents that may be linked to geographic location, such as bacteria (CASTRO; URBANO; COSTA, 2009; RODRIGUES et al, 2017).

The seasonal variation in the incidence of KD is well recognized, but rates change between countries. In the UK, Australia and the USA, there is a higher number of cases in winter and spring. In China and Korea, in spring and summer. In the US and uk, the rise in rates is more correlated with the variation of rainy periods than with temperature variation. In Brazil, a study conducted with 70 patients with KD showed a higher record of the disease coinciding with periods of higher incidence of infectious diseases from May to June (beginning of drought) and November and December (early rains) (MAGALHÃES; ALVES, 2017).

A person with $K D$ develops symptomatological characteristics that lead to the presentation of a clinical picture, which consists of the set of signs and symptoms manifested by the patient (KAYIRAN; DINDAR; GURAKAN, 2010). Thus, the clinical picture of $K D$ is characterized by cervical lymphadenopathy, fever, tonsillitis, swelling of the limbs, rash, itching and flaking (ATIK, 2007; SCARDINA et al., 2007). In addition, KD can cause generalized inflammation, affecting some organs causing inflammatory cardiomyopathy, sterile meningitis, hepatitis, adenolinfite, pericarditis, and angitis (CASTRO; URBANO; COSTA, 2009). 
Castro, Urbano and Costa (2009) point to a relationship between vasculitis caused by $\mathrm{KD}$ and the involvement of some organs, which consist of grouping of tissues responsible for the maintenance of the organism.

KD was first reported in 1967 by japanese physician Tomisaku Kawasaki, who defined it as "mucocutaneous lymph node syndrome". During this period, 50 cases were reported in the years 1961 to 1967. In Japan, the occurrence is higher, and the global distribution has its variable prevalence (ALMEIDA et al., 2010; SCARDINA et al., 2007; MAGALHÃES; ALVES, 2017).

In the current scenario, some epidemiological data on KD have already been established, allowing a more accurate analysis of the factors that intervene in the diffusion and spread of diseases. Many studies have been conducted in order to understand the pathophysiology of the disease, which consists of a set of abnormal changes caused in the body (CASTRO; URBANO; COSTA, 2009).

In one study, evidence of KD and the advance of other comorbidities were found, which refers to the fact that two or more diseases are at the same time in an individual, so the complications of KD would be the unfavorable evolution of this association (SCARDINA et al., 2007).

To improve the care and quality of life of the Patient with KD, treatments were developed, which consist of ways of caring for a patient (CASTRO; URBANO; COSTA, 2009).

\section{GOALS}

Detail the possible causatous agents, pathophysiology, the main organs and anatomical structures affected by Kawasaki Disease (KD).

To verify the main characteristics of an individual's clinical picture for diagnosis, the main associated complications, and the treatments available for patients with KD. 


\section{METHOD}

This is a bibliographic research carried out in the databases, Scielo, Brazilian Digital Library of Theses and Dissertations, LILACS and PubMed, using keywords or their associations: Kawasaki-Kawasaki disease.

The inclusion parameters used in the preparation of the searches were the comprehensive availability online, the direct approach on Kawasaki Disease (DK) or on some aspect pertinent to this disease. In the Scielo database there were text filters of the productions written in English and Portuguese, in the other databases this criterion was not used. The exclusion parameters applied were duplicated and performed before the year 2000 .

An analysis was made in the databases mentioned to list the articles related to KD in the literature. From a previous reading of the titles and abstracts of the scientific productions found, studies that did not correspond to what was expected to constitute this review were discarded. The complete texts that went through the previous stages were read, selecting for this review those that addressed relevant aspects of KD.

\section{RESULTS}

\section{POSSIBLE CAUSATOUS AGENTS OF DK}

The cause of Kawasaki disease is still unknown. However, its clinical and epidemiological characteristics feed the hypothesis that an infectious agent is the triggering cause, which produces changes in the cells, tissues and organs of individuals with genetic predisposition. This hypothesis is the most likely, but it still has no proof (CASTRO; URBANO; COSTA, 2009).

One of the theories is that of coronavirus NL-63, detected by means of a Polymerase Chain Reaction (PCR) in airway fluids of 11 patients with KD and in only 1 of the 22 control patients. However, another 5 later studies did not find coronavirus in 
respiratory or nasopharite tissue samples from patients, making it impossible for this virus to be the triggering cause (CASTRO; URBANO; COSTA, 2009).

Another theory is that of immunological stimulation by bacterial superantigens such as staphylococcal and streptococcal toxins. A third theory is immunological, which proposes that KD be caused by an aberrant immune response in genetically predisposed individuals (MAGALHÃES; ALVES, 2017).

\section{PHYSIOPATHOLOGY OF DK}

The alterations found in KD, especially histological ones, characterize a picture of generalized systemic angiitis, affecting mostly vessels of median caliber, especially the coronary arteries. In several organs, infamous changes can be observed, such as in the myocardium, in the pericardium, in the blood vessels, in the meninges, in the lung, in the lymph nodes and in the liver (CASTRO; URBANO; COSTA, 2009).

\section{MAIN ANATOMICAL ORGANS AND STRUCTURES AFFECTED BY DK}

KD affects organs and arteries, mainly vessels of medium caliber from various systems of the human body, such as cardiovascular, pulmonary, gastrointestinal (intestine and gallbladder are the main affected organs) and the central nervous system (SNC). However, it should be highlighted the implication that this disease has in the heart, with the formation of coronary aneurysms (CASTRO; URBANO; COSTA, 2009).

Other arteries may also be affected, such as: aortic aneurysm, with a greater number of reported cases compromising the abdominal aorta; axillary artery aneurysm; brachiocephalic artery aneurysm; aneurysms of iliac arteries, femoral; renal artery aneurysm and ocular artery obstruction (ALVES et al., 2011).

\section{MAIN FEATURES OF THE CLINICAL PICTURE OF AN INDIVIDUAL FOR THE DIAGNOSIS OF DK}


Fever, which marks the acute phase of the disease, is usually elevated (above $39^{\circ} \mathrm{C}$ ) and at peaks, temporarily decreasing in intensity lasting approximately seven to fourteen days, and may reach three and/or four weeks if there is no appropriate treatment. The day on which the fever begins is considered the first day of the disease. However, some patients have other classic manifestations before fever, such as: non-purulent conjunctivitis; cervical lymph nodemegaly; erythemas and/or edemas on the hands and feet; exanthetem escalatiniform, morbiliform or polymorphic; framboesiform tongue, erythema and oropharynx edema, fissures and labial erythema (CASTRO; URBANO; COSTA, 2009).

Changes in the extremities (hands and feet) with erythemas and/or edema also appear in the acute phase, and edema is very painful and is associated with palmoplantar erythema with vasculitis at the fingertips that after a period of one to two weeks, already in the subacute phase, begins to peel, starting by the periungueal region in the glove finger (MAGALHÃES; ALVES, 2017).

Non-exudative bilateral conjunctivitis especially affects the bulbar conjunctiva when compared to the palpebral and tarsal conjunctiva and is painless. Sometimes it is accompanied by iridocyclitis, an inflammation of the anterior part of the eye, with rapid resolution and little associated with sensitivity to light (CASTRO; URBANO; COSTA, 2009).

Polymorphic rash is a set of rashes that occur in the first days of the disease, mainly affecting the trunk and extremities, without apparent blisters or vesicles. They have variable presentation (urticariform rash, morbiliform, maculopapular) or diffuse, resembling scarlet fever (ALMEIDA et al., 2010).

Changes in the lips and oral cavity 9 out of 10 cases in the acute phase with intense labial and oropharynx hyperemia, fissures, dry mucosa and bleeding of the lips. Tongue papillae may become prominent and oral ulcerations with oropharynx exudato may sometimes be observed. Regarding cervical lymphadenomegaly, another diagnostic criterion, the patient must present at least one lymph node with a 
diameter greater than or equal to $1.5 \mathrm{~cm}$, commonly unilateral, painful and firm, in the anterior cervical triangle (ALMEIDA et al., 2010; MAGALHÃES; ALVES, 2017).

\section{THE MAIN COMPLICATIONS ASSOCIATED WITH DK}

In patients with $\mathrm{KD}$, three types of vasculopathies are identified at different moments in the evolution of the disease: necrotizing arteritis, subacute/chronic arteritis and luminal myofibroblastic proliferation vasculitis. In the acute phase of the disease, necrotizing arteritis stands out, which has its complete pathological process in the first two weeks after the beginning of the febrile condition, especially in the coronary arteries, which may determine the formation of giant aneurysms susceptible to the development of thrombosis and ruptures. In the subacute phase, it is verified that the process of subacute vasculitis begins 2 weeks after the onset of fever, and may affect all blood vessels, especially the middle segment of the middle muscle arteries, such as the coronary arteries. In the chronic phase of the disease, luminal fibroblastic myoproliferation occurs, associated with chronic subacute vasculitis (MAGALHÃES; ALVES, 2017).

The most serious complication of the disease is coronary vasculitis, with changes in the coronary arteries, which affects $15-20 \%$ of patients who do not receive treatment. These alterations include aneurysms, ectasias and stenoses of the coronary arteries, responsible for $2 \%$ mortality (ALMEIDA et al., 2010).

In the gastrointestinal system, there is vomiting, diarrhea, abdominal pain and paralytic ileus. At the onset of fever, the most frequent manifestations are vomiting and diarrhea and the least common are jaundice, painful hepatomegaly, pancreatitis, and hydropic vesicles. In the respiratory system, the most frequent manifestations are cough, pneumonitis and radiological changes. Rarely occurs rinorreia (MAGALHÃES; ALVES, 2017).

In the SNC, the disease can manifest with extreme irritability in the acute phase, in addition to aseptic meningitis, ataxia, facial paralysis and sensorineural hearing loss. 
Also noteworthy is the presence of ganglionitis and neuritis in cranial and peripheral nerves, endarteritis, periarteritis, choriomeningitis and leptomeningitis, in addition to atrophy, degeneration with loss of neurons, marginal and subpendimal gliosis and formation of glial nodules around neuron degenerations (MAGALHÃES; ALVES, 2017).

Behavioral changes such as attention impairment, learning deficiency, emotional changes (emotional lability, fear and night terror) and internalization problems (anxious, depressive and aggressive behavior) have been described in the literature (ALVES et al., 2011).

\section{TREATMENTS AVAILABLE FOR INDIVIDUALS AFFECTED BY KD}

Therapy for KD has two different purposes depending on the stage in which it is located. In the acute phase, it aims to reduce the inflammatory response in the coronary artery wall and prevent vasculitis and its consequences (thrombosis and aneurysms). In the subacute and chronic phases, the aim is to prevent myocardial ischemia and infarction (CASTRO; URBANO; COSTA, 2009).

Intravenous Immunoglobulin (IGEV) is the main medicine used in KD and its mechanism of action remains unknown. It is used in the acute phase, preferably in the first 7 to 10 days of the beginning of the condition (MAGELLAN; ALVES, 2017).

Treatment consists of the administration of immunoglobulin in a single dose of $2 \mathrm{~g} / \mathrm{kg}$ over a variable period of 10 to 12 hours together with the administration of acetylsalicylic acid (AAS) 80 to $100 \mathrm{mg} / \mathrm{kg} /$ day, orally, 6/6 hours. High-dose AAS has an anti-inflammatory effect and, in low doses, acts as a platelet aggregation inhibitor, so that the time of use of AAS in high doses should remain until the child is afebrile. Then, the dose is reduced to 3 to $5 \mathrm{mg} / \mathrm{kg} / \mathrm{day}$ and maintained at this dose while the patient presents with thrombocytosis and/or coronary changes (MAGALHÃES; ALVES, 2017; RODRIGUES et al., 2017). 
Between 1 and 2 in 10 of patients with KD do not respond to the first dose of IVIG, or with the permanence of the febrile condition or with the reappearance of it one and a half days after the first infusion. These patients are considered refractory to treatment and are the ones with the highest risk of coronary changes. In such cases, administration of the second dose of IVIG of $2 \mathrm{~g} / \mathrm{kg}$ in a single dose is recommended. If fever persists for 36 hours, it is recommended to use pulse therapy with methylprednisolone at a dose of $30 \mathrm{mg} / \mathrm{kg} /$ day (maximum dose $1 \mathrm{~g} / \mathrm{day}$ ), infused at 1 hour, 1 time/day, for 3 days (MAGALHÃES; ALVES, 2017).

In the treatment of KD in the subacute and chronic phases, low-dose aspirin (3$5 \mathrm{mg} / \mathrm{kg} / \mathrm{day}$ ) is used in children with small and medium aneurysms. In these phases, the treatment aims to prevent thrombosis (platelet activation) and vessel ssthesis. Other antiplatelet agents are also used (clopidogrel, ticlopidine, dipyridamol) and, associated with aspirin, are presenting as more concrete in blocking platelet aggregation (CASTRO; URBANO; COSTA, 2009).

\section{DISCUSSION}

\section{CORRELATION BETWEEN POSSIBLE CAUSATORS AND THE DEVELOPMENT OF DK}

To date, the origin of KD has not been identified, but there are some agents, which are believed to be related to the development of the pathology. These are Staphylococcus aureus, estreptococos, vírus influenza, morbilivírus, paramixovírus, bunyavírus. Adenovirus and a new human coronavirus called New Haven coronavirus (Nco-NH) may also be associated with $\mathrm{KD}$, as they have already been identified in respiratory tract secretions of patients with the disease. Such viruses and bacteria could act on the development of KD, so that they would lead to data caused by the disease, such as aortic aneurysms (BARCA et al., 2019; CASTRO; URBANO; COSTA, 2009). 
There is a hypothesis that associates the existence of bacterial superantigens with the development of KD. Studies analyzing this suggestion assume that the superantigen can bind to the antigen-presenting cell, through the class II major histocompatibility complex (Class II MHC) and the T lymphocyte receptor at binding sites different from those of common antigens. This would promote an immunological response with the formation and release of pro-inflammatory cytokines in excessive concentrations, contributing to the evolution of an inflammatory process characteristic of KD (CASTRO; URBANO; COSTA, 2009).

Some indications lead to the believed that an oligoclonal IgA response occurs in acute KD. A study conducted by Castro, Urbano and Costa (2009) performed the analysis of the alpha heavy chain of immunoglobulins collected from a large amount of leukocytes accumulated at an inflammatory response site of the arterial wall of patients with $K D$, which showed that specific immunoglobulin $A(\lg A)$ antibodies were detected in the sample. This evidences the existence of an immune response related to KD (CASTRO; URBAN; COAST, 2009).

The hypothesis that KD has genetic predisposition is enhanced by the high incidence among Asians and their rummies. One study showed 67 genes related to the development of the pathology, which involved involvement in the endothelium, lipid metabolism, activation of immunological mechanisms and platelet recruitment, supporting the idea that there is a genetic relationship for the development of $K D$ (CASTRO; URBANO; COSTA, 2009; SOTELO; GONZÁLEZ, 2007).

\section{PHYSIOPATHOLOGY OF DK}

Vasculitis begins with the occurrence of swelling and inflammation, which can occur for a variable period. Neutrophils are present initially, and soon after there is a predominance of CD8+ cytotoxic T lymphocytes and IgA immunoglobulin (CASTRO; URBAN; COAST, 2009). 
In the coronary arteries there are inflammatory changes with the presence of edema and necrosis of muscle cells. With this loss of structural integrity there is the formation of aneurysms. In addition, fibroblasts proliferate and then remodel, leading to the possible presence of susthesis, calcifications and thrombosis (CASTRO; URBANO; COSTA, 2009; SOTELO; GONZÁLEZ, 2007).

It is important to note that inflammatory factor 1 found in allografts is sharply increased in shimnotic arterial tissues of KD. This inflammatory factor 1 of the allograft binds the response of interferon type I until the activation of specific macrophages and $T$ lymphocytes, which assumes the probable importance of the interference of these cells in the arteritis by KD (ROWLEY et al., 2017).

\section{HOW THE MAIN ORGANS AND ANATOMICAL STRUCTURES ARE AFFECTED BY DK}

$\mathrm{KD}$ affects organs and arteries, mainly medium-sized vessels, such as those of the heart, specifically coronary arteries, with the formation of aneurysms. The disease can also affect the respiratory system (lung), through vasculitis, the gastrointestinal system, mainly the intestine and gallbladder, and the nervous system (CASTRO; URBANO; COSTA, 2009).

The lymphatic system may be affected with $K D$, as one of the symptoms of $K D$ is swelling of the cervical lymph nodes. The cutaneous system is damaged by cutaneous erythema, followed by edemas. In the eyes, non-suputive conjuncture hyperemia may occur and the mucous membranes of the oral cavity may be affected by oral mucositis and lesions on the lips (SOTELO; GONZÁLEZ, 2007).

\section{THE MAIN CHARACTERISTICS OF THE CLINICAL PICTURE OF AN INDIVIDUAL WITH DK AND HOW THEY AFFECT HIM}

The clinical course of KD can be divided into three clinical stages: acute, subacute and convalescence. The acute febrile stage usually lasts from 7 to 14 days, 
characterized by conjunctival congestion, oral mucositis, erythema, flaking and polymorphic rash and lymphadenopathy. The subacute stage is the period between the end of the fever and the 25th day of the disease. At this stage, patients present with skin flaking in the limbs, arthritis, arthralgia and thrombocytosis. The convalescence stage begins when clinical symptoms begin to disappear and continues until the normal establishment of VHS (red blood blood pressure rate), which is usually observed 6 to 8 weeks after the onset of symptoms. Such stages affect the patient's life, since they prevent him from performing his daily activities, which is mainly due to skin lesions and symptomatology (ALMEIDA, 2017; SCARDINA et al., 2007).

The condition suggestive of the pathology is characterized by fever, increased cervical lymph nodes and tonsillitis, followed by generalized cutaneous erythema, itching and edema of the limbs and after a few days of flaking. Laboratory tests show an active inflammatory phase with high sedimentation rate, C-reactive protein, leukocytosis and increased number of platelets, which leads to lethargy of the affected individual, since inflammation can cause severe pain (ALMEIDA, 2018; ATIK; FORONDA; BUSTAMANTE, 2003; FERRONATO et al., 2010; ROSSI et al., 2015).

Non-suputive conjuncture hyperemia may also arise; macular-papular rash; lesions on the lips and oral cavity; changes in the skin of the extremities, in addition to precordial murmur, difficulty breathing, abdominal pain, dysuria, hepatomegaly, arthralgia, stiffening of the neck and convulsions. These symptoms prevent the patient from seeing and getting around normally, since the eyes are damaged and the pain causes difficulty, to perform movements (CASTRO; URBANO; COSTA, 2009; SOTELO; GONZÁLEZ, 2007).

$\mathrm{KD}$ affects several patients with vasculitis in various organs, as has been said earlier, the lung, intestine, gallbladder, central nervous system, are example, which leads to the appearance of symptoms such as fatigue, weight loss and pain in joints and muscles, but cardiac damage is the most significant, with the formation of coronary 
aneurysms, which lead to angina (CASTRO; URBANO; COSTA, 2009; PRINTZ, 2011).

Another symptom is irritation, which appears in children with the disease, and gastrointestinal complaints, including diarrhea, vomiting and abdominal pain, occur in about one third of patients, which explains the fact that children with KD are more irritated than the others (ALMEIDA, 2018; KAYIRAN; DINDAR; GURAKAN, 2010).

Abscess and retropharyngeal edema is usually associated with a fatal condition if not treated properly. Otorhinolaryngologists can treat it with surgical drainage of the abscess, preventing airway block (KIM; KWON, 2016; XIE et al., 2018).

Oral mucositis is represented by diffuse erythema of the mucous membrane, redness in the lips and tongue, and hypertrophy of the lingual papillae with subsequent development of the strawberry tongue, and usually occurs in the acute stage of the disease and convalescence, as a consequence of pharmacological treatment, and prevents the patient from feeding properly due to the lesions, affecting his adequate nutrition (SCARDINA et al., 2007).

\section{THE DIAGNOSIS OF DK}

$\mathrm{KD}$ represents a challenge to be diagnosed early, as it is an unusual rheumatologic disorder that requires specific intervention in order to avoid serious or fatal sequelae (ALMEIDA et al., 2010).

The clinic of the disease is unclear, being common the initial diagnosis of other diseases, such as scarlet fever, viral exantheme or allergic conditions, due to the initial symptoms of the disease. Even with the complete fulfillment of the criteria, it is frequent to delay in the correct diagnosis, which leads to a delay in the beginning of the appropriate treatment, favoring the appearance of complications, which can quickly aggravate the patient's clinical condition. In addition, there are incomplete or atypical forms, which make diagnosis even more difficult. Early diagnosis of the disease is important, as treatment in the acute phase reduces the inflammatory 
process in the coronary arteries and prevents thrombosis, reducing the chances of mortality (FERRONATO et al., 2010).

Timely clinical diagnosis is essential to establish this early treatment and avoid coronary lesions. This type of injury can cause ischemia or myocardial infarction, which is extremely severe (KAYIRAN; DINDAR; GURAKAN, 2010; SOTELO; GONZÁLEZ, 2007).

The diagnostic criteria of classical KD disease are fever with five days or more, in addition to at least four other criteria, which are: palmoplantar erythema with or without painful edema or periunigueal flaking; Polymorphic exatheme; bulbar conjunctival hyperemia on both sides, not exudative; Changes in the lips and oral mucosa; Cervical lymphadenopathy - diameter greater than $1.5 \mathrm{~cm}$, hard and painless on palpation. The diagnosis of incomplete KD can be established in the presence of three or more of the following criteria: Albumin $\leq 3 \mathrm{~g} / \mathrm{dL}$; Anemia; Elevation of alanine aminotransferase; Platelets after seven days $\geq 450,000 / \mathrm{mm}^{3}$; Leukocytes $\geq 15,000 / \mathrm{mm}^{3}$; Urine $\geq 10$ leukocytes (CASTRO; URBANO; COSTA, 2009; RODRIGUES et al., 2017; YAP; LIN; WANGUI, 2012).

The main sequelae of the disease are related to the cardiac system, therefore, cardiac imaging by echocardiography is a relevant part of the evaluation of patients with suspected KD. For uncomplicated cases, echocardiography is recommended at diagnosis, 6 to 8 weeks after the onset of the disease (ATIK et al., 2017; KAYIRAN; DINDAR; GURAKAN, 2010)

The most frequentlaboratory alterations are blood count with leukocytosis and neutrophilia, in addition to increasing the values of acute phase tests, such as hemosedimentation velocity and C-reactive protein. The disease is often diagnosed only after coronary artery involvement (FERRONATO et al., 2010).

A study by Kentsis et al. (2013) found that filamine $C$ and meprina A markers were detected in both serum and urine of the two independent groups of participating KD patients. The same study finds the use of these markers to perform the diagnosis of 
$\mathrm{KD}$ as being more efficient than the use of markers currently used (KENTSIS et al., 2013).

\section{IMAGE EXAMS AND COMPLEMENTARY}

Echocardiogram is one of the main tests used for the diagnosis of $K D$, since it is not invasive, has a high sensitivity and specificity to analyze and detect abnormalities in the coronary arteries, evaluate the myocardium and verify the presence of pericarditis. In this examination, some findings may appear that indicate coronary arteritis, which precedes the formation of aneurysms, such as perivascular brightness, ectasia or narrowing of the coronary arteries. In the analysis of coronary arteries, the internal diameter of the vessel should be evaluated; the number, location and type (whether saccular or fusiform) of aneurysms; and the presence or not of intraluminal thrombus and susthesis. In the acute phase of the disease, some frequent findings in echocardiograms are: reduction of left ventricle contractility, regurgitation of the mitral valve and pericardial effusion (CASTRO; URBANO; COSTA, 2009; MAGALHÃES; ALVES, 2017; RODRIGUES et al., 2017).

Other tests that can be performed, based on availability, severity, advantages and indications that vary according to the case. For example, magnetic resonance imaging (RNM), angioresonance, chest X-ray, high-resolution computed tomography, angiography (CASTRO; URBANO; COSTA, 2009).

CT angiography, an invasive examination that has risks, and angioresonance are usually performed in those patients who have presented abnormality on electrocardiogram, echocardiographic or symptoms of myocardial ischemia (CASTRO; URBANO; COSTA, 2009; MAGALHÃES; ALVES, 2017).

Lately, high-resolution computed tomography has been more indicated, especially when compared to $\mathrm{MRI}$, since its execution is faster and easier to interpret, while MRI requires a longer anesthetic time of children for collection (CASTRO; URBANO; COSTA, 2009). 
Chest X-ray, which usually does not present alterations, in approximately $15 \%$ of cases anomalies are discovered, such as: pattern of reticulogranular or peribronchial infiltrate, accumulation of too much liquid in the space between the visceral and parietal pleuras or collapse of the lung. They appear after the 10th day of the disease and are possible to check on radiographs 10 to 50 days after the beginning of the condition (CASTRO; URBANO; COSTA, 2009).

In laboratory tests, the findings are not specific to $K D$, but rather an indication of a high inflammatory process and it is possible to find, at the beginning of the acute phase, an increase in hemosedimentation velocity (VHS), C-reactive protein (PCR) and acid alphaglycoprotein rates. In the blood test it is possible to check an abnormally high amount of neutrophils, called leukocytosis with neutrophilia, and may be accompanied by increased bats or eosinophilia. Moreover, the amount of platelets is usually normal in the acute phase, however, it is possible that in some cases there is thrombocytopenia, which is associated with the development of severe coronary disease and myocardial infarction (MAGALHÃES; ALVES, 2017).

\section{ANALYSIS OF THE MAIN COMPLICATIONS ASSOCIATED WITH DK}

The most serious complication of the disease is coronary vasculitis, which affects 15$20 \%$ of untreated patients, which may lead to aneurysms, ectasias and susthesis of the coronary arteries, which account for $2 \%$ mortality. Other complications of KD have been described as aneurysms in other arteries such as the aorta; the abdominal aorta; axillary artery; brachiocephalic artery; iliac arteries, femoral arteries and renal arteries, which indicates how DK can vastly affect the human body, and thus be extremely dangerous (ALVES, et al., 2011; CHBEIR et al., 2018; MUTLUER; ÇELIKER, 2019; PRINTZ, 2011; XIE et al., 2018).

Some patients with KD are susceptible to progressive coronary dilation. Such coronary artery dilation occurs during the acute phase and may proceed to the subacute phase, which aggravates the clinical condition of several patients (BRIEDÉ et al., 2015; 2015; LIU et al., 2017). 
Gastrointestinal complications in KD can occur such as intestinal obstruction, colon edema, intestinal ischemia, intestinal pseudo-obstruction, and acute abdomen, which affects the patient alarmingly, as these complications can lead to sepsis and even death. In addition, ophthalmologic alterations associated with KD may include uveitis, iridocyclitis, conjunctival hemorrhage, optic neuritis, amaurosis, and obstruction of the ocular artery, which causes irreparable sequelae several times. KD also manifests as necrotizing vasculitis, thus leading to loss of affected tissue (ALVES, et al., 2011).

Neurological complications due to cns injury may be as follows: meningoencephalitis, subdural collection, cerebral hypoperfusion, ischemia, cerebral infarction, seizures, emiplegia, mental confusion, lethargy, and even coma or cerebral infarction. Such complications can become irreversible, thus forever harming the patient's life (ALVES, et al., 2011).

The risk of late complications of KD suggests the need for long-term follow-up in addition to childhood (GIACCHI et al., 2014).

\section{TREATMENTS AVAILABLE FOR INDIVIDUALS AFFECTED BY KD}

The most indicated treatment is the application of IVIG (Intravenous Immunoglobulin) in a single dose of $2 \mathrm{~g} / \mathrm{kg}$ per 12-hour infusion. According to the evolution of the patient's clinical quaro, the dose of IGIV may be repeated or corticosteroids may be added, especially in refractory cases. Other drugs are recommended, such as cyclophosphamide, cyclosporine, and ulinastatin. Also, a product based on monoclonal antibodies against tumor necrosis factor alpha is recommended, as well as a monoclonal antibody, known as Abciximab, and which can treat aneurysms more quickly (ATIK, 2007; FERRONATO et al., 1010; KAYIRAN; DINDAR; GURAKAN, 2010; PHILIP et al., 2017; SOTELO; GONZÁLEZ, 2007).

Approximately 10 to $15 \%$ of patients with KD show no improvement with IGIV treatment, which is the standard treatment (MEHNDIRATTA et al., 2014). In pediatric 
patients with $\mathrm{KD}$, high doses of acetylsalicylic acid (AAS) provide anti-inflammatory action, while low doses have an inhibitory effect of platelet aggregation. Thus, in the acute phase of the disease, ASA $80-100 \mathrm{mg} / \mathrm{kg} / \mathrm{day}$ is used, which is divided into four ingestions throughout the day, in order to intensify the anti-inflammatory effect of IVIG. While in some hospitals the dose of AAS is reduced after 2-3 days in the absence of fever, in other health centers treatment persists for up to 2 weeks. In addition, children with cardiac abnormalities have a prescription for hearing aas indefinitely (ATIK, 2007; CASTRO; URBANO; COSTA, 2009; MEHNDIRATTA et al., 2014).

Immunosuppressive drugs such as cyclophosphamide are also used, together with prednisone or methylprednisolone, to improve some symptoms, such as fever, but these medications do not have a therapeutic effect on cardiac abnormalities (CASTRO; URBAN; COSTA, 2009; PHILIP et al., 2017).

In the acute phase of KD disease, there is a higher surgical risk because, in the presence of inflammation, anastomosis with inflamed coronary artery runs the risk of obstruction. The surgical approach should be restricted to patients with giant aneurysms or ischemic processes after the acute phase (ATIK, 2007; SOTELO; GONZÁLEZ, 2007).

Surgical revascularization of coronary lesions secondary to $K D$ is relatively uncommon. According to current guidelines, complete arterial revascularization should be used in young patients with small comorbidities in order to obtain a good long-term graft permeability (BARCA et al., 2019).

In addition to myocardial revascularization surgery, which has been the treatment of choice for thrombotic coronary complications of $\mathrm{KD}$, percutaneous coronary intervention (ICP) with regular or percutaneous stents with polytetrafluoroethylene (PTFE), coil implantation, percutaneous transluminal coronary revascularization (PTCR) with thrombolytic agents in the infarction-related artery, and percutaneous 
coronary rotational ablation (PTCRA), are being used in patients affected by the disease (MUTLUER; ÇELIKER, 2019).

As for anesthetic management, there is little information described, however, myocardial revascularization with anesthesia performed by halogenated gases presents less damage, thus showing better postoperative recovery of myocardial function compared to intravenous anesthetics. Thus, it favors the inhibition of neuroendocrine response to stress, and also prepares the patient for an early extubation in the postoperative period, which helps in the prevention of possible complications arising from intubation (MARTÍNEZ; MÉNDEZ, 2013).

\section{CONCLUSION}

The occurrence of $K D$ is variable, being more present in the Asia region, especially in children under 5 years of age. In Latin America the incidence is less frequent and the mortality of this pathology is low.

The etiological agent of KD has not been identified, but there are some pathogens that may be related to this disease. There is evidence that this disease has a genetic relationship, this was found due to the increased incidence among Asian people and among relatives of patients affected by KD, in addition, there are also some genes that are associated with this pathology.

There are alterations associated with KD such as systemic inflammations, affecting certain organs caused by angiitis, sterile meningitis, pneumonitis, adenofinite and hepatitis. KD affects organs and arteries, mainly medium-caliber vessels, such as those of the heart, so that leads to the formation of aneurysms, can affect the eyes, mucous membranes of the oral cavity, the lung, intestine, gallbladder and nervous system, lymphatic system, skin system and lesions may occur in the lips.

The clinical picture of KD has three stages. The acute febrile stage is characterized by conjunctival congestion, oral mucositis, erythema, flaking, polymorphic rash, and laterocervical lymphadenopathy. The subacute stage occurs at the end of fever, 
patients have skin flaking on the limbs, arthritis, arthralgia and thrombocytosis. The convalescence stage arises when the symptoms are almost disappearing and continues until their normalization.

The delay in the correct diagnosis of KD is quite frequent, which may lead to a delay in the beginning of treatment, which may cause complications to worsen the clinical condition. Early clinical diagnosis is extremely important to establish early treatment and avoid coronary artery injuries.

Treatment of KD is based on the evolution of the patient's clinical picture. The most used therapy is the application of IGIV, if changes occur in the clinic, the dose of IVIG may be repeated or corticosteroids may be added. Other medicines may be indicated, such as cyclophosphamide, cyclosporine, and ulinastatin. It is also recommended a product based on monoclonal antibodies Infliximab, immunosuppressants such as cyclophosphamide or cyclosporine and prednisone or methylprednisolone may be used. Surgical treatment is done mainly in the acute phase of KD, but should be restricted to patients with giant aneurysms or ischemic processes after the acute phase of the disease.

\section{REFERENCES}

ALMEIDA, F. C. Avaliação das manifestações clínicas e achados laboratoriais em 301 pacientes com doença de Kawasaki: acompanhamento de dez anos. Tese (Doutorado em Ciências Médicas). Faculdade de Medicina, Universidade de Brasília, Brasília. 2018.

ALMEIDA, M. A. A. L. S. Avaliação da calprotectina e dos anticorpos anticitoplasma de neutrófilos como marcadores de inflamação e autoimunidade nas diferentes fases da doença de Kawasaki. Dissertação (Mestrado em Ciências Farmacêuticas). Faculdade de Ciências da Saúde, Universidade de Brasília, Brasília. 2017. 
ALMEIDA, R. G. et al. Perfil da doença de Kawasaki em crianças encaminhadas para dois serviços de reumatologia pediátrica do Rio de Janeiro, Brasil. Revista Brasileira de Reumatologia, v. 50, n. 5, p. 529-538, set./out. 2010.

ALVES, N. R. M. et al. Estudo prospectivo das complicações da Doença de Kawasaki: análise de 115 casos. Revista da Associação Médica Brasileira, v. 57, n. 3, p. 299-305, mar. 2011.

ATIK, E. Doença de Kawasaki: Regressão de Aneurismas Gigantes das Artérias Coronárias com Obstrução Tardia Posterior Kawasaki Disease: Giant Coronary Arteries Aneurysms Regression and Later Stenosis. Arquivos brasileiros de Cardiologia, v. 88, n. 1, p. 22-23, 2007.

ATIK, E.; FORONDA, A.; BUSTAMANTE, L. N. P. Kawasaki Disease. Involution of Giant Coronary Aneurysms After Prolonged Anti-inflammatory Treatment. Arquivos brasileiros de Cardiologia, v. 81, n. 3, p. 265-72, set. 2003.

ATIK, E. et al. Caso 6/2017 - Extenso Aneurisma Gigante de Artéria Coronária Esquerda por Vasculite de Kawasaki em Homem Assintomático com 48 Anos de Idade. Arquivos brasileiros de Cardiologia, v. 109, n. 5, p. 489-490, nov. 2017.

BARCA, L. V. et al. Ligature of the Left Main Coronary Artery after Surgery in Kawasaki Disease: Case Report. Braz J Cardiovasc Surg, v. 34, n. 1, p. 111-113, jan./fev., 2019.

BRIEDÉ, S. et al. Hamoen M, Oosterveld M JS, Breur JMPJ. Langetermijneffecten van de ziekte van Kawasaki. Ned tijdschr geneeskd, v. 154, n. 2121, p. 1-6, out. 2015.

CASTRO, P. A.; URBANO, L. M. F.; COSTA, I. M. C. Doença de Kawasaki. Anais Brasileiros de Dermatologia, v. 84, n. 4, p. 317-331, mai. 2009. 
CHBEIR, D. et al. Kawasaki disease: abnormal initial echocardiogram is associated with resistance to IV Ig and development of coronary artery lesions. Pediatric Rheumatology Onlinw Journal, v. 6, n. 48, p. 1-10, jul. 2018.

FERRONATO, A. E. et al. Doença de Kawasaki: experiência clínica em hospital universitário. Revista Paulista de Pediatria, v. 28, n. 2, p. 148-154, jun. 2010.

GIACCHI, V. et al. Avaliação do espessamento íntimo da artéria coronária em pacientes com diagnóstico prévio de doença de Kawasaki por meio de ecocardiografia transtorácica de alta resolução: nossa experiência. BMC Cardiovasc Disord, v. 14, n. 106, p 1-6, ago. 2014.

HUANG, X. et al. Influenza infection and Kawasaki disease. Revista da Sociedade Brasileira de Medicina Tropical, v. 48, n. 3, p. 243-248, jun. 2015.

KAYIRAN, S. M.; DINDAR, A. N.; GURAKAN, B. An evaluation of children with Kawasaki disease in Istanbul: a retrospective follow-up study. Clinical Science, v. 65, n. 12, p. 1261-1265, dez. 2010.

KENTSIS, A. et al. Urine proteomics for discovery of improved diagnostic markers of Kawasaki disease. EMBO Mol Med, v. 5, n. 2, p. 210-220, fev. 2013.

KIM, J. S.; KWON, S. H. Atypical Kawasaki disease presenting a retropharyngeal abscess. Braz J Otorhinolaryngol, v. 82, n. 4, p. 484-486, 2016.

LIU, M. Y. et al. Risk factors and implications of progressive coronary dilatation in children with Kawasaki disease. BMC Pediatrics, v. 17, n. 139, p. 1-7, jun. 2017.

MAGALHÃES, C. M. E. Estudo da prevalência da perda auditiva neurossensorial como complicação da doença de Kawasaki. Tese (Doutorado em Ciências da Saúde) - Faculdade de ciências da saúde, Universidade Federal de Brasília, Brasília. 2008. 
MAGALHÃES, C. M. R.; ALVES, N. R. M. Doença de Kawasaki. In: I. Burns, DAR, Campos Júnior D, Silva LR, Borges WG. Tratado de pediatria: Sociedade Brasileira de Pediatria. 4. ed. Barueri, SP: Manole, 2017. p.1825-1835.

MARTÍNEZ, U. M.; MÉNDEZ, F. M. Manejo anestésico del paciente com enfermedad de Kawasaki durante la cirugía de revascularización coronaria: informe de um caso. Archivos de Cardiología de México, v. 83, n. 4, p. 267-272, abr. 2013.

MEHNDIRATTA, S. et al. A case of incomplete and refractory Kawasaki disease: Diagnostic and therapeutic challenges. The South African Journal of Child Health, v. 8, n. 1, p. 37-38, fev. 2014.

MUTLUER, F. O.; ÇELIKER, A. Comment on Ligature of the Left Main Coeonary Artery after Surgery in Kawasaki Disease: Case Report. Brazilian Journal of Cardiovascular Surgery, v. 34, n.3, p. 382, jul. 2019.

PHILIP, S. et al. Role of Antioxidants in Horse Serummediated Vasculitis in Swine: Potential Relevance to Early Treatment in Mitigation of Coronary Arteritis in Kawasaki Disease. Pediatrics and Neonatology, v. 58, n. 4, p. 328-337, fev. 2017.

PRINTZ, B. F. Noncoronary Cardiac Abnormalities Are Associated With Coronary Artery Dilation and With Laboratory Inflammatory Markers in Acute Kawasaki Disease. Journal of the American College of Cardiology, v. 57, n. 1, p. 68-92, jan. 2011.

RODRIGUES, M. et al. Doença de Kawasaki e Complicações Cardiovasculares em Pediatria. Birth and growth medical jornal, v.27, n. 1, p. 54-58, fev. 2017.

ROSSI, F. S. et al. Extensa linfadenite cervical mimetizando adenite bacteriana como primeira manifestação da doença de Kawasaki. Einstein, v. 13, n. 3, p. 426429, jul./set. 2015.

ROWLEY, A. H. et al. Allograft Inflammatory Factor-1 Links T-Cell Activation, Interferon Response, and Macrophage Activation in Chronic Kawasaki Disease 
Arteritis. Journal of the Pediatric Infectious Diseases Society, v. 6, n. 3, p. 94102, set. 2017.

SCARDINA, G. A. et al. Oral necrotizing microvasculitis in a patient affected by Kawasaki disease. Medicina Oral Patologia Oral y Cirugia Bucal, v. 12, n. 8, p. 560-564, dez. 2007.

SOTELO, N.; GONZÁLEZ, L. A. Kawasaki disease: A rare pediatric pathology in Mexico Twenty cases report from the Hospital Infantil del Estado de Sonora. Archivos de Cardiologia de Mexico, v. 77, n. 4, p. 299-307, dez. 2007.

XIE, X. F. et al. Proteomics study of serum exosomes in Kawasaki disease patients with coronary artery aneurysms. Cardiology Journal, v. 26, n. 5, p. 584-593, fev. 2018.

YAP, C. Y.; LIN, L. H.; WANGI, N. K. An atypical presentation of Kawasaki disease: a 10- year-old boy with acute exudative tonsillitis and bilateral cervical lymphadenitis. CLINICS, v. 67, n. 6, p. 689-692, 2012.

Submitted: April, 2021.

Approved: April, 2021. 